\title{
PENERAPAN OPERASI MORFOLOGI MATEMATIKA CITRA DIGITAL UNTUK EKSTRAKSI AREA PLAT NOMOR KENDARAAN BERMOTOR
}

\author{
Agus Susanto \\ Program Studi Rekayasa Sistem Komputer, Fakultas Ilmu Komputer, Universitas Dehasen Bengkulu \\ J1. Meranti Raya No.32, Sawah Lebar, Ratu Agung, Bengkulu, 38222
}

agus.susantodunived.ac.id

\begin{abstract}
Abstrak: Peneleitian ini bertujuan untuk mengekstrak area plat nomor dari citra kendaraan bermotor menggunakan operasi morfologi matematika. Data input yang digunakan adalah citra kendaraan bermotor roda dua yang memiliki plat nomor dengan jumlah 50 citra. Proses ekstraksi area plat dilakukan dengan 4 (empat) tahap yaitu tahap pra pengolahan citra kendaraan, tahap deteksi tepi citra kendaraan, tahap pencarian area plat dengan operasi morfologi, dan tahap pelabelan dan pemotongan area plat. Tahap pra pengolahan dilakukan untuk normalisi ukuran citra dan konversi RGB ke grayscale. Tahap deteksi tepi diterapkan pada citra grayscale dengan menggunakan operator sobel. Tahap pencarian area plat dilakukan menggunakan operasi morfologi yang meliputi dilasi, filling, dan opening. Hasil pengujian menunjukkan bahwa operasi morfologi dapat diterapkan untuk pencarian area plat nomor dengan baik, sehingga diperoleh hasil ekstraksi citra plat nomor yang baik pula. Hal ini ditunjukkan dengan persentase keberhasilan ekstraksi citra sebesar $80 \%$.

Kata Kunci: Pengolahan Citra, Morfologi Matematika, Ekstraksi Plat Nomor
\end{abstract}

Abstract: This research aimed to extract the number plate area from the vehicles images using mathematical morphology operations. The input data used were 50 vehicle images including its number plate. The plate area extraction process was carried out with 4 (four) stages, namely the pre-processing, edge detection, plate area searching with morphological operations, and the labeling and cropping. The pre-processing stage was carried out for image size normalization and RGB to grayscale conversion. The edge detection stage was applied to grayscale images using the sobel operator. The plate area searcing was carried out using mathematical morphology operations which included dilation, filling, and opening. The test results show that morphological operations can be applied to search the number plate area well, so that the number plate image extraction results are obtained as well. This is indicated by the percentage of image extraction success of $80 \%$.

Keywords: Image Processing, mathematical morphology, Plat Number Extraction

\section{Pendahuluan}

Kendaraan bermotor merupakan alat transportasi darat yang paling banyak digunakan di berbagai negara termasuk di Indonesia. Hal ini dapat dilihat dari jumlah kendaraan bermotor yang dimiliki masyarakat semakin meningkat. Meningkatnya jumlah kendaraan ini disebabkan oleh beberapa faktor, seperti meningkatnya taraf hidup dan kemudahan akses untuk mendapatkan kendaraan bermotor. Meningkatnya jumlah kendaraan tersebut dapat menimbulkan permasalahan dalam transportasi, seperti kemacetan, pelanggaran lampu lalu lintas, kecelakaan lalu lintas, dan lain-lain.

Untuk meminimalisir permasalahan transportasi tersebut, maka diperlukan upaya yang bersifat ilmiah dan berteknologi tinggi. Salah satu 
Jurnal Pseudocode, Volume VI Nomor 1, Februari 2019, ISSN 2355-5920

www.ejournal.unib.ac.id/index.php/pseudocode

upaya yang dapat dilakukan adalah dengan membangun dan menerapkan sistem transportasi cerdas (intelligent transportation). Pembangunan sistem transportasi cerdas mampu menyediakan banyak data tentang kendaraan yang dapat digunakan untuk penindaklanjutan, analisis, dan pemantauan [1].

Setiap kendaraan bermotor memiliki identitas khusus berupa Tanda Nomor Kendaraan Bermotor (TNKB) atau yang sering disebut dengan plat nomor kendaraan. Plat nomor ini berupa kombinasi antara karakter huruf dan angka yang berfungsi untuk membedakan antara kendaraan yang satu dengan yang lainnya. Plat nomor kendaraan ini dapat menjadi topik menarik untuk diteliti berkaitan dengan pembangunan sistem transportasi cerdas. Salah satu bagian paling penting dari sistem transportasi cerdas adalah pengenalan karakter plat nomor [2].

Pengenalan karakter plat nomor kendaraan merupakan suatu aplikasi yang memanfaatkan teknik pengolahan citra digital dan pengenalan pola. Sistem pengenalan karakter plat nomor kendaraan dikembangkan untuk mendeteksi lokasi dari plat nomor dalam suatu citra dan mengenali karakter-karakter yang ada dalam plat nomor tersebut secara otomatis [3]-[5].

Pendeteksian lokasi plat nomor kendaraan merupakan faktor penting yang mempengaruhi keberhasilan proses pengenalan karakter. Deteksi lokasi plat nomor pada suatu citra memerlukan suatu teknik yang berhubungan dengan bentuk geometri. Salah satu teknik dalam pengolahan citra digital yang berhubungan dengan bentuk geometri adalah teknik morfologi matematika. Morfologi matematika merupakan pendekatan berbasis topologi dan bentuk geometri untuk melakukan analisis pada citra dan menjadi suatu alat yang sangat berguna untuk mengekstrak struktur dan bentuk geometri di banyak aplikasi [6].

Berdasarkan uraian di atas, penulis tertarik untuk menerapkan operasi morfologi matematika dalam pengolahan citra digital untuk mengekstrak bagian plat nomor dari suatu citra kendaraan khusunya untuk jenis kendaraan sepeda motor.

\section{LANDASAN TEORI}

\section{A. Citra Digital}

Citra didefinisikan sebagai fungsi $f(x, y)$, berukuran $M$ baris dan $N$ kolom, dimana $x$ dan $y$ adalah koordinat spasial dari citra, sedangkan $f(x, y)$ merupakan intensitas atau tingkat keabuan dari citra pada titik tersebut. Apabila nilai $x, y$, dan $f$ secara keseluruhan memiliki nilai yang berhingga (finite) dan bernilai diskrit, maka citra tersebut disebut dengan citra digital [7].

Citra digital tersusun atas elemen-elemen bilangan berhingga yang memiliki lokasi tertentu. Representasi citra digital dinyatakan dalam bentuk matrik berukuran $M \times N$ seperti dinyatakan dalam Persamaan 1

$$
f(x, y)=\left[\begin{array}{cccc}
f(0,0) & f(0,1) & \cdots & f(0, N-1) \\
f(1,0) & f(1,1) & \cdots & f(1, N-1) \\
\vdots & \vdots & \vdots & \vdots \\
f(M-1,0) & f(M-1,1) & \cdots & f(M-1, N-1)
\end{array}\right]
$$

Kedua ruas dari persamaan ini merupakan cara ekivalen dalam menyatakan citra digital. Ruas kanan dari Persamaan 1 merupakan matrik bilangan ril. Setiap elemen dalam matrik ini disebut sebagai image element, picture element, pixel, atau pel [8].

Sebuah citra adalah kumpulan piksel-piksel yang disusun dalam bidang dua dimensi. Indeks baris dan kolom $(x, y)$ dalam sebuah piksel dinyatakan dengan bilangan bulat. Piksel $(0,0)$ terletak pada sudut kiri atas pada citra, indeks $x$ bergerak ke kanan dan indeks $y$ bergerak ke 
Jurnal Pseudocode, Volume VI Nomor 1, Februari 2019, ISSN 2355-5920

www.ejournal.unib.ac.id/index.php/pseudocode

bawah. Ilustrasi tentang sistem koordinat citra digital ditunjukkan pada Gambar 1 [7].

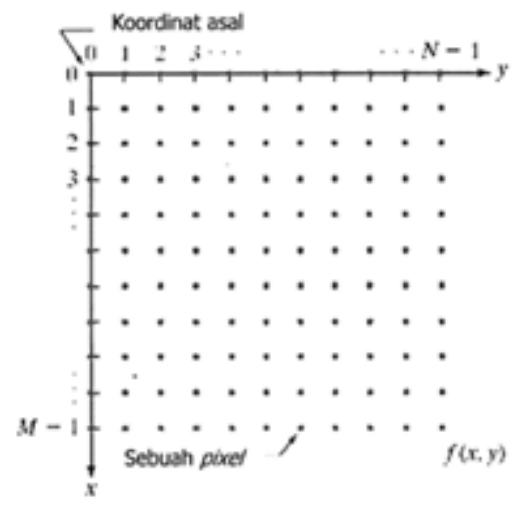

Gambar 1. Sistem Koordinat Citra Digital

\section{B. Citra Grayscale}

Citra grayscale merupakan citra digital yang hanya memiliki satu nilai kanal pada setiap pikselnya, dengan kata lain bagian Red, Green, dan Blue memiliki nilai yang sama. Nilai terseut digunakan untuk menunjukkan tingkat intensitas. Warna yang dimiliki adalah warna dari hitam, keabuan, dan putih. Tingkat keabuan di sini merupakan warna abu dengan berbagai tingkatan dari hitam hingga mendekati putih [7].

Citra grayscale juga sering disebut dengan citra beraras keabuan. Nilai intensitas pada citra beraras keabuan merupakan nilai tunggal dengan nilai intensitas berada pada interval 0 sampai 255 , sedangkan pada citra berwarna perlu tiga nila intensitas yang berada pada interval 0 sampai 255 untuk setiap pikselnya. Semakin mendekati 255, maka derajat keabuan akan semakin terang. Pada dasarnya proses ini dilakukan dengan meratakan nilai piksel dari tiga nilai RGB menjadi satu nilai. Namun karena ketiga warna pokok tersebut dianggap tidak seragam dalam hal kemampuan kontribusi pada kecerahan, ada yang berpendapat bahwa cara konversi yang lebih tepat adalah dengan menggunakan Persamaan 3 [9].

$$
Y=0,299 R+0,587 G+0,114 B
$$

Di mana $Y$ adalah nilai kecerahan suatu piksel pada citra grayscale, dengan persentase 29,9\% warna merah, 58,7\% dari warna hijau, dan 11,4 dari warna biru.

\section{Deteksi Tepi Menggunakan Metode Sobel}

Deteksi tepi (edge detection) pada suatu citra adalah suatu proses yang menghasilkan tepi-tepi dari obyek-obyek gambar. Suatu titik $(x, y)$ dikatakan sebagai tepi (edge) dari suatu citra bila titik tersebut mempunyai perbedaan yang tinggi dengan tetangga. Deteksi tepi dengan metode Sobel merupakan teknik deteksi tepi dengan cara menempatkan operator sobel 3 x 3. Operator Sobel menempatkan penekanan atau pembobotan pada piksel-piksel yang lebih dekat dengan titik pusat jendela [9].

Kelebihan dari metode sobel ini adalah kemampuan untuk mengurangi noise sebelum melakukan perhitungan deteksi tepi. Kernel filter yang digunakan dalam metode Sobel ini adalah sebagai berikut [10].

$$
h=\left[\begin{array}{lll}
-1 & 0 & 1 \\
-2 & 0 & 2 \\
-1 & 0 & 1
\end{array}\right] \quad \text { dan } \quad h=\left[\begin{array}{ccc}
1 & 2 & 1 \\
0 & 0 & 0 \\
-1 & -2 & -1
\end{array}\right]
$$

\section{Morfologi Matematika Citra Digital}

Morfologi matematika merupakan pendekatan berbasis topologi dan bentuk geometri untuk melakukan analisis pada citra dan menjadi suatu alat yang sangat berguna untuk mengekstrak struktur dan bentuk geometri di banyak aplikasi [6]. Operasi-operasi yang menjadi dasar morfologi matematika adalah sebagai berikut.

Operasi Dilasi: Operasi dilasi (dilation) akan menyebabkan pertumbuhan ukuran objek dengan menukar tiap nilai piksel dengan nilai maksimum 
Jurnal Pseudocode, Volume VI Nomor 1, Februari 2019, ISSN 2355-5920

www.ejournal.unib.ac.id/index.php/pseudocode

piksel tetangga di sekelilingnya. Hal ini akan meningkatkan jumlah piksel tepi objek di citra. Ukuran dan bentuk structuring element akan menentukan jumlah elemen yang akan ditambahkan ke dalam citra. Contoh dilasi citra ditunjukkan pada Gambar 2.

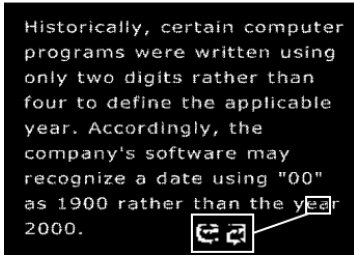

(a)

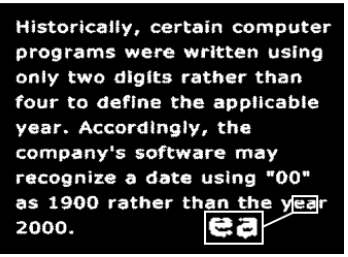

(b)
Gambar 2. Contoh Dilasi (a) Citra Asli (b) Citra Hasil Dilasi

Operasi Erosi: Operasi erosi (erotion) merupakan kebalikan dari operasi dilasi karena akan mengurangi jumlah piksel dengan menukar nilai tiap piksel dengan nilai minimun piksel tetangga di sekelilingnya. Hal ini berdampak pada hilanganya tepi objek pada citra. Contoh erosi citra ditunjukkan pada Gambar 3.

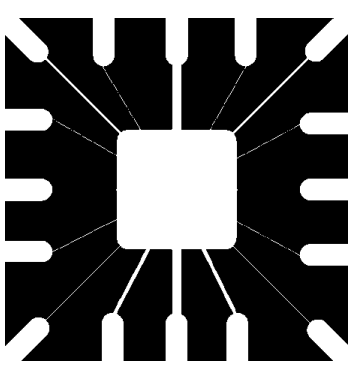

(a)

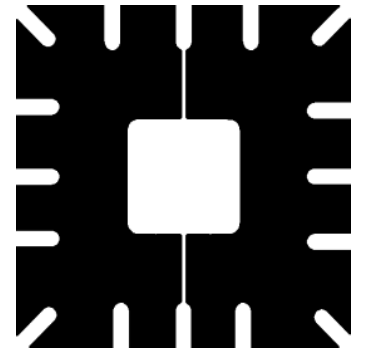

(b)
Gambar 3. Contoh Erosi (a) Citra Asli (b) Citra Hasil Erosi

Operasi Opening: Operasi opening adalah operasi erosi yang diikuti dengan operasi dilasi. Operasi ini akan menghilangkan semua daerah piksel yang terang secara keseluruhan pada citra. Contoh opening pada citra ditunjukkan pada Gambar 4.

Operasi Closing: Operasi closing adalah kebalikan dari operasi opening dengan menerapkan dilasi diikuti dengan erosi. Hasil operasi ini cenderung akan memperbesar daerah tepi dalam citra sekaligus mengecilkan warna background pada daerah tersebut. Operasi ini dapat digunakan untuk menjaga daerah background yang berbentuk sama dengan structuring element. Contoh closing pada citra ditunjukkan pada Gambar 5.

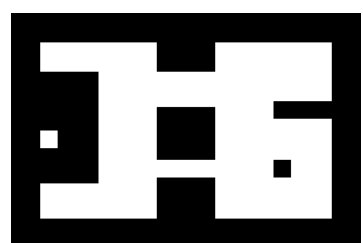

(a)

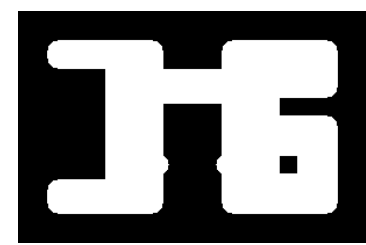

(b)
Gambar 4. Contoh Opening (a) Citra Asli (b) Citra Hasil Opening

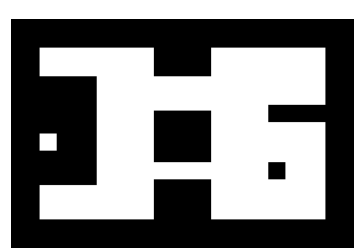

(a)

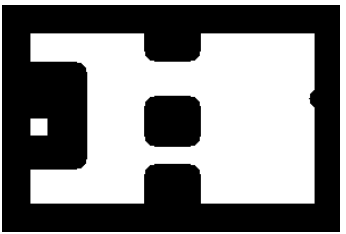

(b)
Gambar 5. Contoh Closing (a) Citra Asli

(b) Citra Hasil Closing

\section{METODE PENELITIAN}

\section{A. Persiapan Data}

Data yang digunakan dalam penelitian ini adalah citra kendaraan bermotor roda dua yang memiliki plat nomor standar yang diambil menggunakan kamera digital. Data citra ini disimpan dalam format *jpg untuk digunakan sebagai masukan awal dari serangkaian proses yang akan dilakukan. Penelitian ini menggunakan 50 data citra kendaraan, beberapa contohnya di tunjukkan pada Gambar 6.
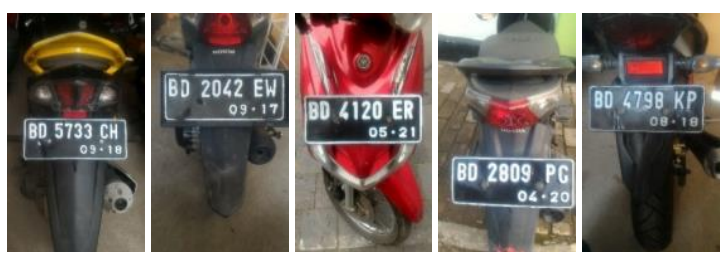

Gambar 6. Contoh Data Citra Kendaraan yang Digunakan 
Jurnal Pseudocode, Volume VI Nomor 1, Februari 2019, ISSN 2355-5920

www.ejournal.unib.ac.id/index.php/pseudocode

\section{Perangkat Lunak dan Perangkat Keras}

Perangkat keras (hardware) dan perangkat lunak (software) yang digunakan dalam penelitian ini secara berturut-turut disajikan pada Tabel 1 dan Tabel 2

Tabel 1. Perangkat Keras yang Digunakan dalam Penelitian

\begin{tabular}{|c|l|l|}
\hline No & Perangkat Keras & \multicolumn{1}{|c|}{ Spesifikasi } \\
\hline 1 & Laptop & $\begin{array}{l}\text { Prosesor Intel Core i7, RAM 8 } \\
\text { GB, Hardisk 1 TB, Grafik } \\
\text { AMD Radeon }\end{array}$ \\
\hline 2 & Kamera & $\begin{array}{l}\text { Kamera bawaan telepon } \\
\text { gengam ASUS Zenfone 2 } \\
\text { dengan resolusi 13 mega pixel }\end{array}$ \\
\hline
\end{tabular}

Tabel 2. Perangkat Lunak yang Digunakan dalam Penelitian

\begin{tabular}{|c|l|l|}
\hline No & Perangkat Lunak & Spesifikasi \\
\hline 1 & Sistem Operasi & $\begin{array}{l}\text { Microsoft Windows 10 Home } \\
\text { Edition 64 bit }\end{array}$ \\
\hline 2 & Aplikasi Matlab & R2012b 64 Bit \\
\hline
\end{tabular}

\section{Proses Ekstraksi Bagian Plat Nomor}

Proses ekstraksi bagian plat nomor bertujuan untuk mendapatkan bagian plat nomor kendaraan tanpa bagian lain dari kendaraan. Proses ekstraksi bagian plat nomor yang dilakukan dalam penelitian ini ditunjukkan pada Gambar 7.

Berdasarkan Gambar 7 terlihat bahwa terdapat empat tahap. Tahap pertama adalah pra pengolahan citra kendaraan. Proses ini meliputi normalisasi ukuran citra dan konversi RGB ke Grayscale. Tahap kedua adalah Deteksi Tepi Sobel. Deteksi tepi (edge detection) ini bertujuan untuk meningkatkan penampakan garis batas atau daerah pada citra kendaraan grayscale. Tahap ketiga adalah pencarian area plat pada citra kendaraan menggunakan operasi morfologi. Operasi morfologi yang digunakan meliputi dilasi, filling, dan opening (vertikal dan horizontal).

Seluruh tahapan proses ekstraksi bagian plat nomor kendaraan pada Gambar 7 dilakukan menggunakan Matlab R2012b.

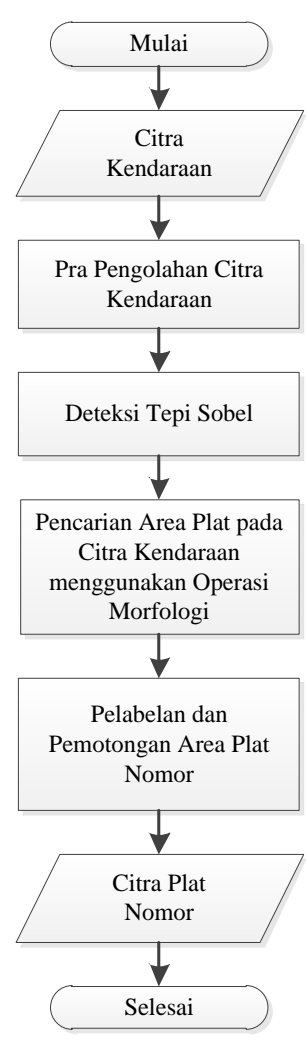

Gambar 7. Proses Ektraksi Bagian Plat Nomor Kendaraan

\section{HASIL DAN PEMBAHASAN}

\section{A. Tahap Pra Pengolahan Citra Kendaraan}

Tahap pra pengolahan yang dilakukan dalam pnelitian ini meliputi normalisasi ukuran citra dan konversi citra RGB ke Grayscale.

Normalisasi ukuran citra: proses ini dilakukan untuk menyeragamkan ukuran citra masukan karena pada awalnya citra kendaraan masukan memiliki ukuran yang belum seragam, sehingga jika masih dipertahankan ukuran yang sebenarnya, maka akan berpengaruh pada hasil pengolahan citra. Normalisasi ukuran yang diterapkan pada tinggi citra sedangkan lebar citra akan mengikuti perbandingan tinggi citra. Tinggi citra dalam penelitian ini dinormalisasi ukurannya menjadi 480 piksel. Contoh citra hasil normalisasi ukuran ditunjukkan pada Gambar 8.

Konversi Citra RGB ke Grayscale: Tujuan dari proses ini adalah untuk menyederhanakan citra 
Jurnal Pseudocode, Volume VI Nomor 1, Februari 2019, ISSN 2355-5920

www.ejournal.unib.ac.id/index.php/pseudocode

dengan tiga lapisan (layer) warna, yaitu merah (red), hijau (green), dan biru (blue) menjadi satu lapisan warna. Contoh citra hasil konversi RGB ke Grayscale ditunjukkan pada gambar 9.

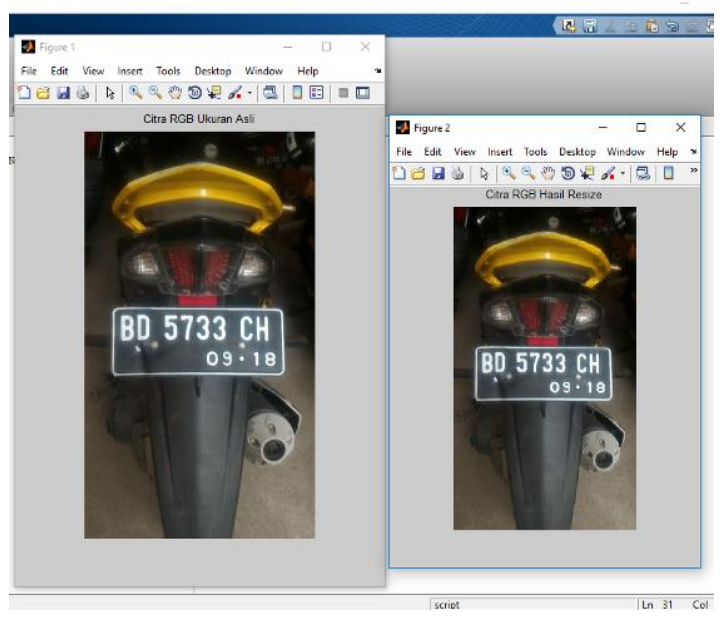

Gambar 8. Citra Hasil Normalisasi Ukuran

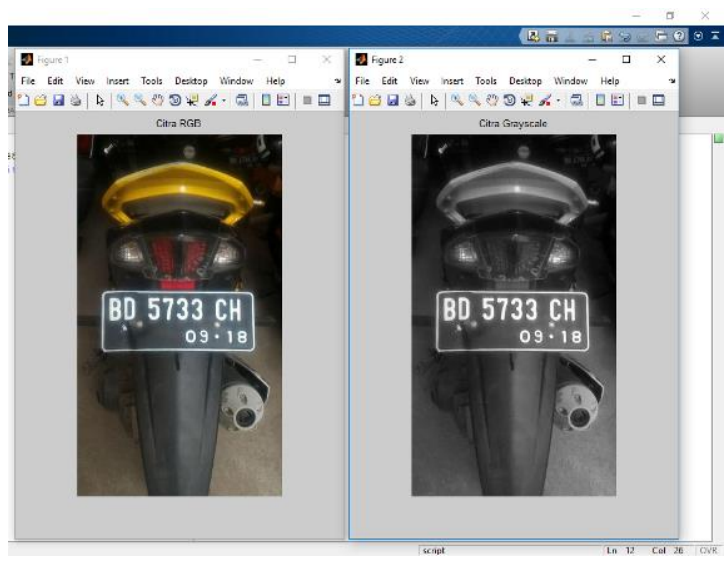

Gambar 9. Citra Hasil Konversi RGB ke Grayscale

\section{B. Tahap Deteksi Tepi Sobel}

Deteksi tepi (edge detection) bertujuan untuk meningkatkan penampakan garis batas atau daerah pada citra grayscale. Proses deteksi tepi yang digunakan dalam penelitian ini adalah deteksi tepi dengan operator Sobel. Penerapan operator Sobel dalam deteksi tepi dikarenakan kemampuannya dalam menghilangkan derau (noise) pada citra. Contoh citra hasil deteksi tepi menggunakan oprator sobel ditunjukkan pada Gambar 10.

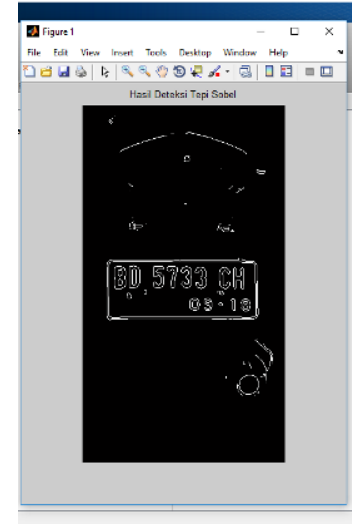

Gambar 10. Contoh Citra Hasil Deteksi Sobel

\section{Tahap Pencarian Area Plat Menggunakan} Operasi Morfologi

Tahap pencarian area plat nomor dari citra kendaraan dilakukan dengan operasi morfologi. Operasi morfologi yang diterapkan dalam penelitian ini meliputi dilasi, filling, dan opening.

Dilasi: Operasi dilasi dilakukan untuk penumbuhan atau penebalan objek pada citra. Operasi dilasi yang akan digunakan dalam penelitian ini akan menggunakan structuring element (strel) dalam bentuk disk dengan radius 1 piksel. Efek yang dihasilkan dari penggunaan strel ini adalah struktur tepi citra yang tersebar ke segala arah. Contoh citra hasil dari dilasi ini ditunjukkan pada Gambar 11(a). Terlihat pada gambar 11(a) bahwa tepi citra lebih tebal.

Filling: Operasi filling bertujuan untuk merekontruksi citra, seperti adanya lubang yang memutuskan suatu objek dalam citra. Lubang yang terjadi pada citra muncul sebagai akibat adanya perbedaan nilai intensitas pada daerah tertentu. Dengan kata lain operasi filling akan membawa nilai intensitas pada daerah gelap yang dikelilingi oleh area terang ke tingkat intensitas daerah yang sama dengan piksel sekitarnya. Jenis filling Matlab yang digunakan dalam penelitian ini adalah Holes. Contoh citra hasil dari filling ini ditunjukkan pada 
Jurnal Pseudocode, Volume VI Nomor 1, Februari 2019, ISSN 2355-5920

www.ejournal.unib.ac.id/index.php/pseudocode

Gambar 11(b). Pada gambar tersebut objek area plat nomor terlihat lebih jelas, namun, masih terdapat objek lain yang bukan area plat.

Operasi opening bertujuan untuk menghilangkan dan menghaluskan garis-garis tipis yang terdapat pada objek dalam citra. Operasi opening yang akan diterapkan meliputi dua operasi, yaitu operasi opening vertikal dan operasi opening horozontal. Tujuannya adalah untuk menghilangkan objek-objek yang terputus baik secara vertikal maupun horizontal. Kedua operasi Opening menggunakan structuring element (strel) dalam bentuk disk dengan radius 15 piksel. Contoh citra hasil opening vertikal dan horizontal ditunjukkan pada Gambar 11(c) dan 11(d).

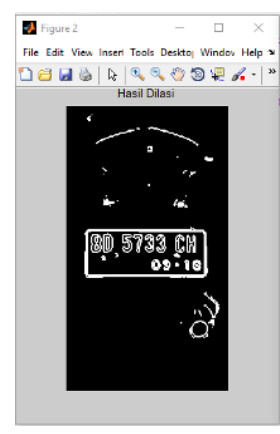

(a)

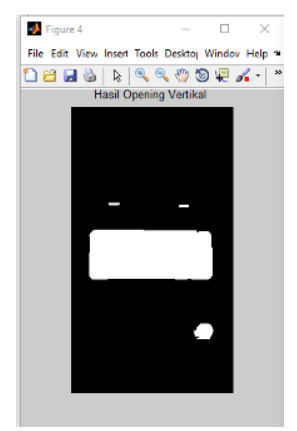

(c)

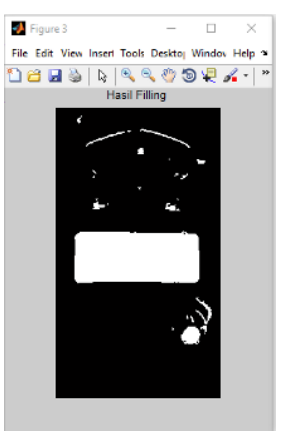

(b)

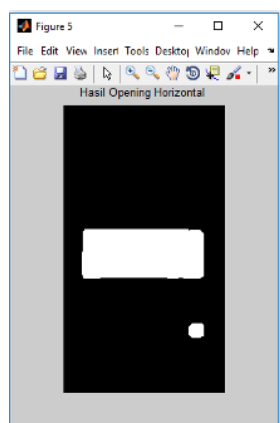

(d)
Gambar 11. Hasil Operasi Morfologi (a) Hasil Dilasi (b) Hasil Filling (c) Hasil Operning Vertikal (d) Hasil Opening Horizontal

\section{Tahap Pelabelan dan Pemotongan Area Plat}

Operasi morfologi yang diterapkan pada citra telah membentuk sekumpulan objek berwarna putih. Pada tahap ini akan dilakukan pelabelan pada objek berwarna putih tersebut untuk menandai area plat nomor yang selanjutnya dilakukan pemotongan area plat. Pelabelan diterapkan terhadap area objek berwarna putih dengan luas paling besar diantara objek putih yang lain. Gambar 12 menunjukkan contoh hasil pelabelan.

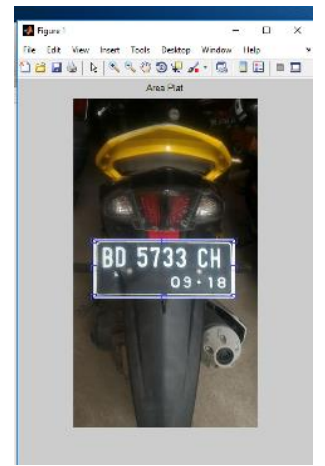

Gambar 12. Contoh Hasil Pelabelan

Setelah proses pelabelan berhasil selanjutnya dilakukan pemotongan (crop) area citra yang telah terindikasi sebagai area plat. Hasil akhir dari bagian deteksi lokasi plat ini adalah citra plat nomor kendaraan yang sesungguhnya. Gambar 13 menunjukkan contoh hasil pemotongan yang tepat pada area plat.

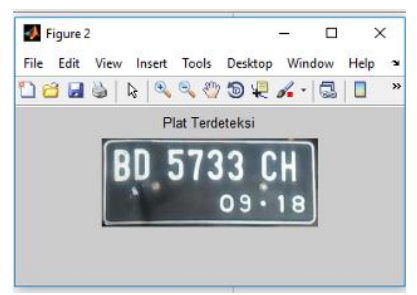

Gambar 13. Contoh Hasil Pemotongan Plat yang Tepat

Citra plat seperti ditunjukkan pada Gambar 13 merupakan hasil akhir yang diinginkan dalam penelitian ini, yaitu citra plat nomor kendaraan yang utuh. Namun demikian, tidak semua data citra yang digunakan dapat diekstrak secara tepat. Contoh hasil ekstraksi plat yang tidak tepat ditunjukkan pada Gambar 14. 
Jurnal Pseudocode, Volume VI Nomor 1, Februari 2019, ISSN 2355-5920

www.ejournal.unib.ac.id/index.php/pseudocode

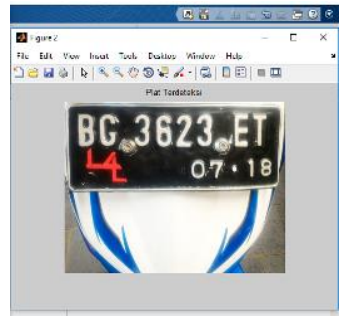

Gambar 14. Contoh Hasil Ekstraksi Plat yang Tidak Tepat

Terlihat pada Gambar 14 citra plat yang terekstrak memiliki bagian kendaraan lainnya sehingga dikatakan hasil ekstraksi yang tidak tepat.

\section{E. Pengujian Seluruh Data Citra Kendaraan}

Hasil pengujian ekstraksi dari 50 data citra yang digunakan dalam penelitian ini disajikan pada Tabel 3 .

Tabel 3. Hasil Ekstraksi Bagian Plat Nomor

\begin{tabular}{|c|c|c|c|}
\hline No & Nama Plat & Nomor Plat & Hasil Eksraksi \\
\hline 1 & Plat (1) & BD $5733 \mathrm{CH}$ & Tepat \\
\hline 2 & Plat (2) & BD 6544 ER & Tepat \\
\hline 3 & Plat (3) & BD 6734 CB & Tepat \\
\hline 4 & Plat (4) & BD $3779 \mathrm{GH}$ & Tepat \\
\hline 5 & Plat (5) & BD $4260 \mathrm{CH}$ & Tepat \\
\hline 6 & Plat (6) & BD $6866 \mathrm{DQ}$ & Tepat \\
\hline 7 & Plat (7) & BD $6468 \mathrm{CL}$ & Tepat \\
\hline 8 & Plat (8) & BD $3224 \mathrm{SL}$ & Tidak Tepat \\
\hline 9 & Plat (9) & BD $5928 \mathrm{KR}$ & Tepat \\
\hline 10 & Plat (10) & BD 4414 ER & Tepat \\
\hline 11 & Plat (11) & BD $3693 \mathrm{CJ}$ & Tepat \\
\hline 12 & Plat (12) & BD $2042 \mathrm{EW}$ & Tepat \\
\hline 13 & Plat (13) & BD 2803 PG & Tepat \\
\hline 14 & Plat (14) & BD 5660 SD & Tepat \\
\hline 15 & Plat (15) & BG 3623 ET & Tidak Tepat \\
\hline 16 & Plat (16) & BA $2972 \mathrm{YH}$ & Tepat \\
\hline 17 & Plat (17) & BD $2878 \mathrm{KL}$ & Tepat \\
\hline 18 & Plat (18) & BD $4831 \mathrm{EG}$ & Tepat \\
\hline 19 & Plat (19) & BD 5776 DJ & Tidak Tepat \\
\hline 20 & Plat (20) & BD $4120 \mathrm{ER}$ & Tidak Tepat \\
\hline 21 & Plat (21) & BD $3956 \mathrm{CK}$ & Tidak Tepat \\
\hline 22 & Plat (22) & BD $3681 \mathrm{AW}$ & Tidak Tepat \\
\hline 23 & Plat (23) & BD $5434 \mathrm{CQ}$ & Tepat \\
\hline 24 & Plat (24) & BD 4810 PG & Tepat \\
\hline 25 & Plat (25) & BD 5553 YD & Tepat \\
\hline 26 & Plat (26) & BD $6325 \mathrm{PN}$ & Tepat \\
\hline 27 & Plat (27) & BD $2383 \mathrm{EI}$ & Tidak Tepat \\
\hline 28 & Plat (28) & BD $3803 \mathrm{SG}$ & Tepat \\
\hline 29 & Plat (29) & BD $6965 \mathrm{CC}$ & Tepat \\
\hline 30 & Plat (30) & BD $6393 \mathrm{KO}$ & Tepat \\
\hline 31 & Plat (31) & BD $4798 \mathrm{KP}$ & Tepat \\
\hline 32 & Plat (32) & BD $2051 \mathrm{~EB}$ & Tepat \\
\hline 33 & Plat (33) & BD $3690 \mathrm{CC}$ & Tepat \\
\hline 34 & Plat (34) & BD $4510 \mathrm{CL}$ & Tepat \\
\hline 35 & Plat (35) & BD 5817 YD & Tepat \\
\hline 36 & Plat (36) & BD 5278 DR & Tepat \\
\hline 37 & Plat (37) & BD 5526 CM & Tepat \\
\hline
\end{tabular}

\begin{tabular}{|l|l|l|l|}
\hline No & Nama Plat & Nomor Plat & Hasil Eksraksi \\
\hline 38 & Plat (38) & BD 2793 YE & Tepat \\
\hline 39 & Plat (39) & BD 3155 CD & Tepat \\
\hline 40 & Plat (40) & BD 6796 CL & Tepat \\
\hline 41 & Plat (41) & BD 4906 CN & Tepat \\
\hline 42 & Plat (42) & BD 5368 AW & Tepat \\
\hline 43 & Plat (43) & AA 2788 RA & Tepat \\
\hline 44 & Plat (44) & BA 2038 QQ & Tepat \\
\hline 45 & Plat (45) & BD 6623 CF & Tidak Tepat \\
\hline 46 & Plat (46) & BD 5012 EL & Tepat \\
\hline 47 & Plat (47) & BD 6390 EM & Tidak Tepat \\
\hline 48 & Plat (48) & BD 4692 CE & Tepat \\
\hline 49 & Plat (49) & BG 6613 EU & Tepat \\
\hline 50 & Plat (50) & BD 4596 EE & Tidak Tepat \\
\hline
\end{tabular}

Tabel 3 menunjukkan bahwa terdapat 40 hasil ekstraksi citra plat yang tepat dan 10 hasil ekstraksi citra plat yang tidak tepat. Berdasarkan data tersebut maka persentase hasil ekstraksi plat yang tepat adalah sebagai berikut

$$
\text { Persentase Keberhasilan }=\frac{40}{50} \times 100 \%=80 \%
$$

Dari hasil pengujian deteksi lokasi plat nomor yang telah dilakukan, dapat disimpulkan bahwa teknik pengolahan citra digital yang diterapkan dalam penelitian ini dapat mendeteksi lokasi plat dengan baik. Hal ini ditunjukkan dengan persentase hasil deteksi lokasi plat yang tepat sebesar $80 \%$.

\section{KESIMPULAN DAN SARAN}

\section{A. Kesimpulan}

Berdasarkan hasil penelitian yang telah diperoleh, maka dapat disimpulkan bahwa operasi morfologi dapat digunakan untuk ekstraksi bagian plat nomor kendaraan dengan baik dengan persentase keberhasilan $80 \%$. Keberhasilan ekstraksi area plat nomor kendaraan bermotor menggunakan operasi morfologi sangat dipengaruhi oleh citra masukan, proses pra pengolahan citra, deteksi tepi, dan structuring element (strel) yang digunakan pada masingmasing operasi morfologi. 
Jurnal Pseudocode, Volume VI Nomor 1, Februari 2019, ISSN 2355-5920 www.ejournal.unib.ac.id/index.php/pseudocode

\section{B. Saran}

Saran yang dapat diberikan berdasarkan hasil, penelitian ini adalah memperhitungkan faktor jarak dan cahaya pada saat pengambilan citra. Selain itu penentuan structuring element perlu ditentukan dengan memperbanyak citra uji.

REFERENSI

[1] R. P. Patel, N. M. Patel, and K. Brahmbhatt, "Automatic Licenses Plate Recognition," Int. J. Comput. Sci. Mob. Comput., vol. 2, no. April, pp. 285-294, 2013.

[2] E. K. Vellingiriraj and P. Balasubramanie, "A Novel Approach for Recognition of Tamil Characters in Vehicle Number Plate based on Region Pixel through Surveillance Camera," no. 10, pp. 14-17, 2013.

[3] S. M. Kawade and M. M. Mukhedkar, "A Real Time Vehicle' s License Plate Recognition System," Int. J. Sci. Eng., vol. 1, no. 2, pp. 41-48, 2013.

[4] K. R. Soumya, A. Babu, and L. Therattil, "License Plate Detection and Character Recognition Using Contour Analysis," Int. J. Adv. Trends Comput. Scence Eng., vol.
3, no. 1, pp. 15-18, 2014

[5] P. Hidayatullah, F. Feirizal, H. Permana, Q. Mauluddiah, and A. Dwitama, "License Plate Detection and Recognition for Indonesian Cars," Int. J. Electr. Eng. Informatics, vol. 8, no. 2, pp. 331-346, 2016.

[6] P. Pandya and M. Singh, "Morphology Based Approach To Recognize Number Plates in India," no. 3, pp. 107112, 2011.

[7] D. Putra, Pengolahan Citra Digital. Yogyakarta: CV. Penerbit Andi, 2010.

[8] R. Gonzalez and R. Woods, Digital Image Processing. United States of America: Pearson Prentice Hall, 2007.

[9] A. Usman, Pengolahan Citra Digital dan Teknik Pemrogramannya. Yogyakarta: Graha Ilmu, 2005.

[10] A. Basuki, J. F. Palandi, and Fatchurrochman, Pengolahan Citra Digital Menggunakan Visual Basic. Yogyakarta: Graha Ilmu, 2005. 